\title{
Cave Houses as Arcetypes of Shelter Formation in Capadoccia Region, Turkey
}

\author{
By Pelin Yildiz*
}

Cave houses are the priviliged arcetypes of the concept residence being preserved from ancient periods until today. Sustainability of local natural environments and cultural heritage becomes a global issue, while local sites become learning grounds for global communities. One of the best examples of man's symbiotic relationship with nature is Cappadocia located in Central Anatolia offering many possibilities and outcomes for underground habitation. The formation of these structures, their aesthetical value as a whole, the environmental approaches, sustainability ability of these houses, interior space etc. are being identified multidisciplinary in this paper. The aim of this paper is to mention the historical background, formation and developments of the spatial necessities of human from the ancient times that have been surviving from thousands of years and are still in the function today. The functions of these cave houses in current conditions are also being evaluated and the proposals are indicated. In the results and conclusions the necessities of current conditions regarding the spatial aspects of these cave formations with proposals are being identified. Since almost two thousand years the cave dwellings of Cappadocia play a major role in the regional architecture. During that period many different cultures inhabited this area and used special cave dwellings due to their internalized specific needs. The climate inside is optimal for living and storing: cool in summer and warm in winter. New architectural elements and the needs of modern life should be combined with the local building styles.

\section{Introduction}

Cappadocia, also known as the region of Göreme is situated in Central Anatolia, roughly 200 kilometres Southeast of Turkeys capital Ankara. This wide landscape of volcanic tuffa stone around Erciyas Dagi, a $3916 \mathrm{~m}$ high volcano has been known since at least the neolithic time, because of its special geologic formations and its natural resources, namely obsidian which used to be a famous commodity in pre historian times.

The site's topography adds visual interest and variety to the housing project. The climate is dominated by lack of humidity, big differences between

*Associate Professor, Department of Interior Architecture and Environmental Design, Hacettepe University, Turkey. 
day and night time temperatures. There are three objectives to be mentioned in the cave hose formation ${ }^{1}$.

- To create an innovative building for a town house that will achieve maximum level of desired comfort, but will adhere to energy conservation through all seasons.

- To demonstrate a mechanism which achieve adequate air movement at ground and first floor utilizing traditional method.

- To identify and evaluate the energy efficient architectural building design techniques that comes from traditional architecture.

The interesting rock formations, known as "fairy chimneys", have been formed as the result of the erosion of this tufa layer, sculpted by wind and flood water, running down on the slopes of the valleys. Water has found its way through the valleys creating cracks and ruptures in the hard rock. The softer, easily erodable material underneath has been gradually swept away receding the slopes and in this way, conical formations protected with basalt caps have been created.

Turkish settlements develop without any centralised planning. Their form therefore reminds us of organic grown structures. The different cultural ideas of room design are reflected in the anonymous architecture, though this may often be an aspect outside of the consciousness of the builder. The dichotomous character of spatial and social boundaries plays an important role in the life of oriental people. Outside and inside, above and below, male and female, right and left, cold and warm, or dark and light. Besides the natural and topographic circumstances mentioned above, all those aspects have a strong influence on the building style and have been essential in developing form and construction of housing and its spatial surroundings ${ }^{2}$.

The principles of natural homebuilders one reason that people live in caves is that they offer protection against hurricanes, tornadoes, and fires, and they offer relief from extreme heat and extreme cold. They also are easy to move into, and do not require a great deal of effort to make them habitable. There are five main principles that lie at the core of the natural builder's ethos. These include ${ }^{3}$.

- Minimizing "embodied energy" — the amount of energy and fuel used to process, transport, install, and ultimately recycle what

\footnotetext{
${ }^{1}$ H. Sözer and S. Bekele, Evaluatıon of Innovatıve Sustainable Destgn Technics That Comes From Traditional Architecture, (2011).

${ }^{2}$ A. Emge, "Old Order in New Space: Change in the Troglodytes' Life in Cappadocia, in: Change in Traditional Habitat"; Traditional Dwellings and Settlements Working Paper Series 37, (Berkeley: University of California, 1992).

${ }^{3}$ B. Garrod, and A. Fyall, "Managing Heritage Tourism", Annals of Tourism Research 27, (2000).
} 
goes into buildings and products - by utilizing raw, local materials wherever possible.

- Using simple construction techniques, easily learned, that requires little skill and few tools ${ }^{1}$.

- Avoiding the use of toxic substances, natural and otherwise, that might create health or environmental hazards during manufacture, construction, and habitation.

- Minimizing consumption of scarce, nonrenewable resources, and avoiding environmental pollution during habitation by using alternative, renewable energy sources to the greatest possible extent. This is attained through use of appropriate technologies, and by practicing a lifestyle of simplicity and conservation that is in harmony with the building and its environment ${ }^{2}$.

Most of the energy consumed in Turkey is imported. Besides there is a huge growing demand on the electrical grid due to increased use of electrical equipments such as air conditioning in summer. There are many concerns about wasteful energy management by government and resulting in high electric bills for consumers. Heating, ventilation and air conditioning (HVAC) systems are used for entire year to provide building inside comfort. However, these consume valuable energy resources, like fossil fuels for heating, or electrical energy for the operation of HVAC equipment. The shortage of conventional energy sources, their increasing prices and their environmental impact, have led to re-examination of the general building design practices and the use of HVAC systems ${ }^{3}$.

Conversely, there are some habitual building design techniques that provide sustainable building architecture characteristics and offer comfortable and safe indoor spaces for the residences, while respecting the environment by taking advantage of natural resources. Strategies for energy conservation are specific problems that arise from the characteristics of the building. Each building type and region should be considered differently. To be able to consume less energy in buildings there are two basic options: invest heavily in the purchase, installation, operation and maintenance of HVAC systems; or reduce energy load by applying bioclimatic principles to building design. There is a barrier in today's architecture that while many green buildings can be constructed at comparable or lower cost than conventional buildings, integration of high-performance features can increase initial costs from an average of 2 to 7 percent, depending on the design and extent of added features. The operating costs of heating, cooling, ventilation and lighting can

${ }^{1}$ B. Garrod, and A. Fyall, "Managing Heritage Tourism", Annals of Tourism Research 27, (2000).

${ }^{2} \mathrm{H}$. Sözer and S. Bekele, Evaluatıon of Innovatıve Sustainable Desıgn Technics That Comes From Traditional Architecture, (2011). 
be significant, especially if the design and/or operation of the building are suboptimal. $^{1}$

Besides a lot of qualities and advantages of the men made cave dwellings as living space, the storage capacity of these tuffa cave rooms were one of the major influencing factors of the development of settledness in this area. The cave architecture of Cappadocia is not only distinguished by a "one stone on to the other" work of construction, but so to speak a building style of the "negative", where the inside is scoped out of the tuffa stone. Living space is created by taking away, digging out and removing the material out of the tuffa. Highly functional inside the Cappadocian cave dwellings are invisible from the outside $^{2}$

Being very practical in many ways they have given all inhabitants in every epoch complete freedom to shape habitats according to their specific personal needs. Every niche, every wall shelf is an expansion to the area, enlarging the living area by taking building material out, whereas in a "stone on to stone" architecture the living space becomes smaller by putting things inside. Because in this type of architecture there is no cost for building materials and it's transportation to the sight. It is a very economic building style and also ecologically interesting alternative. Furthermore there are almost no costs in up keeping the structure; no leaking roofs or rotting beams! Therefore we still find cave dwellings that have lasted intact for nearly 2000 years.

The actual living area is usually attainable from this half open hallway and is entered by a threshold which is the intersection between the open and the closed rooms.

Traditional architecture in this region was very particular about their ecological system, climate, culture, functionality, and proportion of the buildings that fits very precisely with the surroundings. That gives a unique style and character that represents the specific environment and culture.

A consciousness of climate integrated with an instinctive understanding of local culture, to result in regionally responsive architecture ${ }^{3}$. This is evident human carved underground cities and sanctuaries.

\footnotetext{
${ }^{1}$ H. Sözer and S. Bekele, Evaluatıon of Innovatıve Sustainable Deslgn Technics That Comes From Traditional Architecture, (2011).

${ }^{2}$ A. Leask, and A. Fyall, "World Heritage sites: Current Issues and future Implications", in Robinson, M., Evans, N., Long, P., Sharpley, R.and Swarbrooke, J. eds. Tourism and Heritage Relationships: Global, National and Local Perspectiives, (Sunderland: Centre for Travel and Tourism and Business Education, 2000).

${ }^{3}$ S. Kinzer, (1997) "Live Better, Live Longer, in My Home, Sweet cave!", The New York Times International, May 2, 1997
} 
Figure 1. Underground City ${ }^{1}$

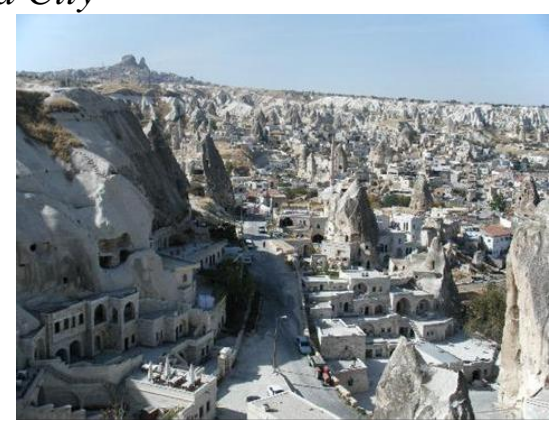

Figure 2. Courtyard

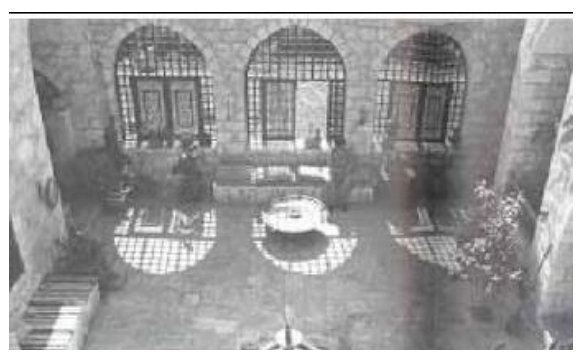

Courtyards can be in different sizes and accommodate multiple functions. It can function as a hall to connect different rooms of a single house, or as a main street for neighborhood, gathering area for a family or common space for families. The size and shape of the courtyards are determined in part by local building techniques and climatic conditions and in part by the local cultural aspects. In addition, they also function in reducing cooling loads in the hot summer climate. At night, cool air comes in and cools the thermally massive courtyard walls and floor and these elements hold the "coolness" throughout the hot day

Application of courtyard concept as a living room makes this space the most important area in the house. One of the major elements of this design concept is the fire place where is located in the middle of the living room. First floor has a galleria, which is looking at this space to the ground floor. Centralized fireplace in the middle of the living area works as a central heater in winter and shutters on the roof around the chimney create a horizontal air circulation in summer ${ }^{2}$.

\footnotetext{
${ }^{1}$ A. Leask, and A. Fyall, "World Heritage sites: Current Issues and future Implications", in Robinson, M., Evans, N., Long, P., Sharpley, R.and Swarbrooke, J. eds. Tourism and Heritage Relationships: Global, National and Local Perspectiives, (Sunderland: Centre for Travel and Tourism and Business Education, 2000).

${ }^{2} \mathrm{H}$. Sözer and S. Bekele, Evaluatıon of Innovatıve Sustainable Design Technics That Comes From Traditional Architecture, (2011).
} 
Figure 3. Section of the House

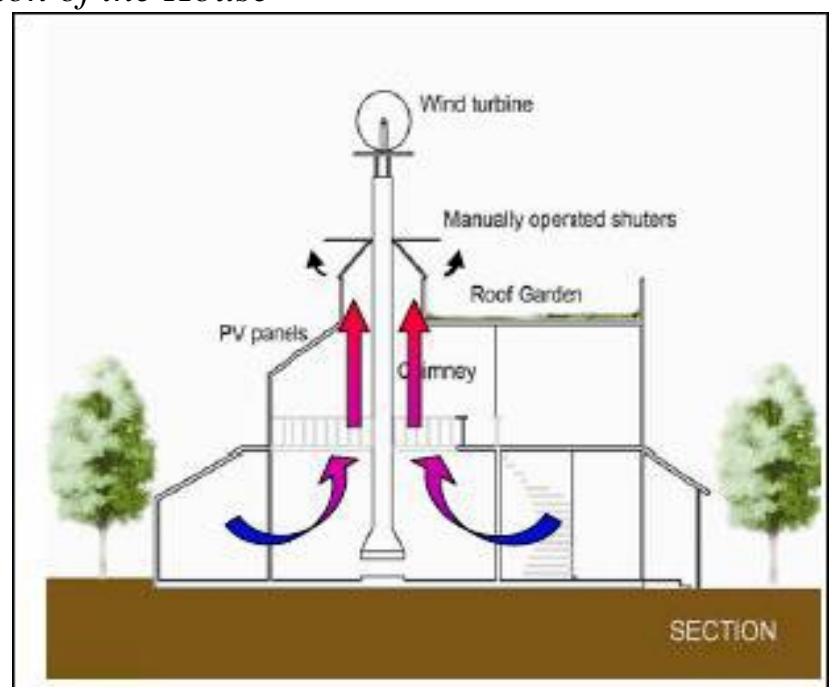

Figure 4. Refectory Monastery at Çanlı Kilise, Reconstructed Plan ${ }^{1}$

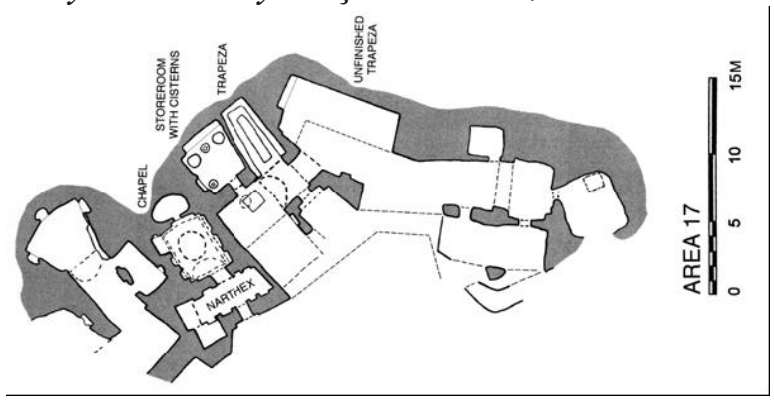

Figure 5. Rock-cut Refectory (trapeza) in Çarılı Kilise, Göreme ${ }^{2}$

Source: photograph by Murat E. Gülyaz

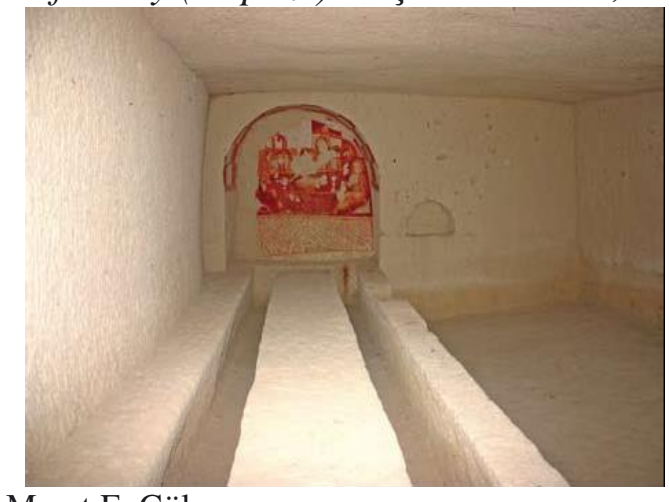

${ }^{1}$ F. G. Öztürk, The Unusual Separatıon of Cappadocıan Refectorles and Kitchens: An Enıgma Of Architectural History, DOI: 10.4305/METU.JFA.2012.1.9, METU JFA 2012/1, (29:1) 2012, 153-169. 
Figure 6. Hallaç, Courtyard Complex, Plan ${ }^{1}$

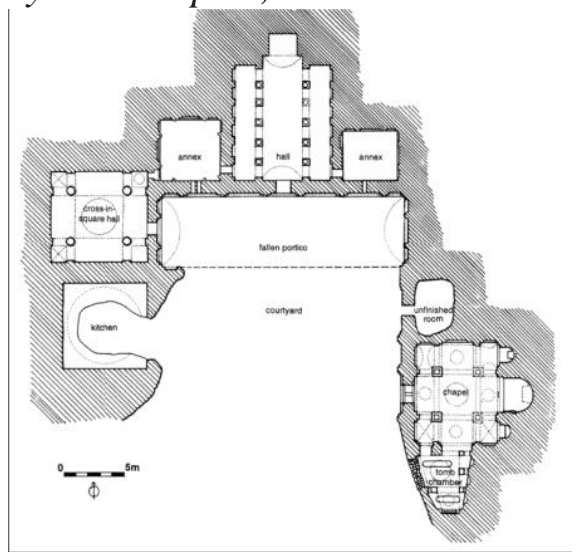

Figure 7. Açıksaray, Area 2

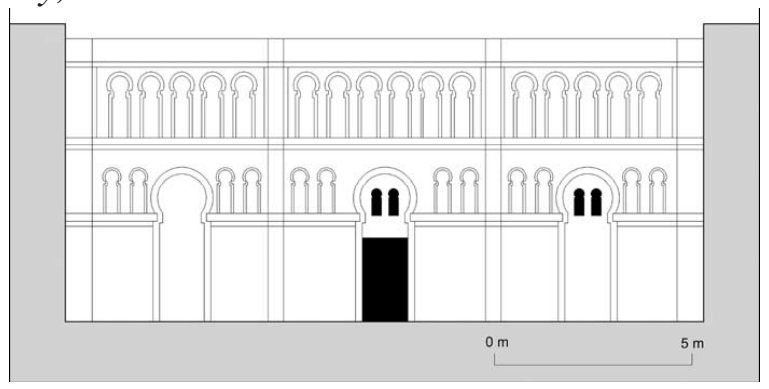

Caves are ecologically-friendly houses. They are the most ecologicallysensitive form of construction, and could be combined with an alternative energy system to become almost completely sustainable. They maintain a constant indoor temperature with natural earth insulation, which also keeps them quiet. They do not require large amounts of inputs in terms of bricks, concrete, mortar, metal, or wood, and do not demand costly synthetic or ecologically-questionable construction materials. In fact, earth caves must be able to "breathe" naturally to last. Requirements for a completed house are limited to a natural floor finish such as terracotta tile or brick, a thin stuccotype wall and ceiling treatment (usually whitewashed; preferably a form of hydrated lime), mechanical systems, and fixtures. Earth caves can also be built to specification. Within certain limitations, one can have high or low ceilings, large or small rooms, curvilinear walls, domed or arched ceilings, alcoves, built-in furniture, and a catalog of sculptural room effects. In fact, building this kind of cave house is like sculpting your house from inside out--a most unique experience. No two cave houses are the same. Given enough land, you can also expand instantly and easily ${ }^{2}$.

${ }^{1}$ F. G. Öztürk, The Unusual Separatıon of Cappadocıan Refectorles and Kitchens: An Enigma Of Architectural History, DOI: 10.4305/METU.JFA.2012.1.9, METU JFA 2012/1, (29:1) 2012, 153-169

${ }^{2}$ B. Bender, Stonehenge: Making Space, Oxford: Berg. Bianchi, R. (2002) 'the contested Landscapes of World Heritage on a Tourist Island: the case of Garajonay National Park, La Gomera, International Journal of Heritage Studies 8, no. 2. (1999). 
Natural light can be provided not only from doors and/or windows facing the outside, but also by light ducts through holes that can be created by modern well-drilling rigs. Such light traps usually have convex Plexiglas covers and reflective ducting that capture and transmit the maximum amount of natural light deep into a cave house. A whitewashed cave interior also reflects more light throughout the interior space than one might think. Caves can even accommodate a fireplace, provided that it is placed relatively near the outside wall of the cave thus keeping chimney construction manageable. Built-in bathtubs, toilet alcoves, and closets are a snap for any experienced cave builder.

In the traditional Turkish way of life usually three generations share a common household under one single roof. Families live virilocal, which means that women move to their husband's families after marriage. The construction of living areas and the choice in the type of housing widely correspond to the preferences of the population inhabiting the area. This holds true for the former Christian population as much as for the Turkish settlers today. There is no question that next to the cultural aspects also natural and geomorphological aspects play a decisive roll in determining the special form a building will display ${ }^{1}$.

Figure 8. Typology of Underground Buildings

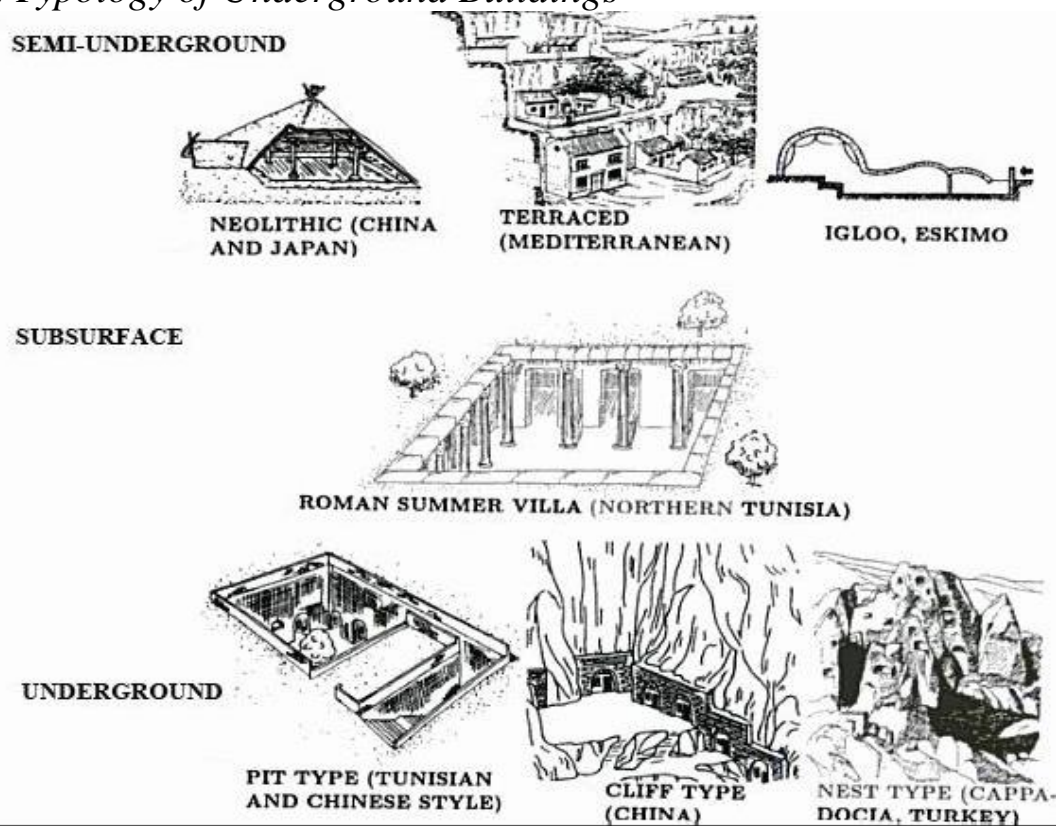

One large problem encountered in cave construction in an urban environment is disposal of the excess earth created during excavation. Such cases require hiring a container and dump truck company to haul away up to hundreds of loads of clay, which can be expensive. This problem is

\footnotetext{
${ }^{1}$ A. Emge, Old Order in New Space: Change in the Troglodytes' Life in Cappadocia, in: Change in Traditional Habitat; Traditional Dwellings and Settlements Working Paper Series, 37, (Berkeley: University of California, 1992).
} 
compounded by the fact that naturally-compacted clay expands in volume by three to four times once excavated ${ }^{1}$.

Figure 9. The New Additional Construction of a Cave House

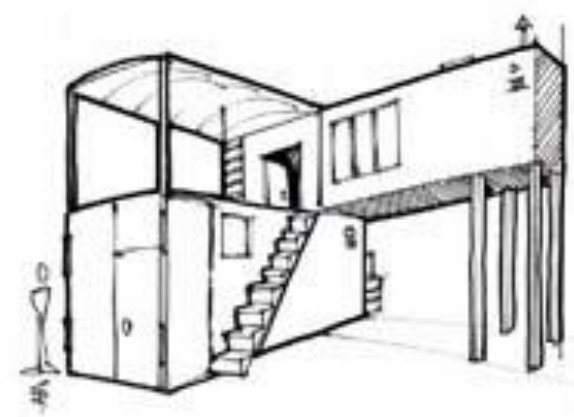

Many cave houses have a small outer part of the house built with conventional construction. This protects the cave entrance and provides extra space. Services such as electricity and water can also enter here. Alternatively, there can simply be a doorway into the earth, usually with a brick frame and a door of decorative wrought iron, to allow as much light as possible into the cave $^{2}$.

The traditional form of Anatolian settlements is determined by the "oriental style ground-plan". Planless paths and roads run outward from the village centre connecting the households and living-quarters with each other whichmeans that the network at the same time also connects every house directly to the village centre. Paths branch out, sometimes interrupted by small squares from which dead-end ways emerge, leading to specific households.

\section{Advantages of Underground Buildings}

There are many advantages to underground construction. Underground buildings are less susceptible to the impact of extreme outdoor air temperatures, so they won't be felt the effects of adverse weather as much as in conventional buildings. Temperatures inside them are more stable than in conventional buildings, and with less temperature variability, interior spaces seem more comfortable. Because earth covers part or entire of their exterior, underground buildings require less outside maintenance, such as painting and cleaning gutters or other exterior material. Constructing a building that is dug into the earth or surrounded by earth, builds in some natural soundproofing. Plans for most underground buildings "blend" the buildings into the landscape

\footnotetext{
${ }^{1}$ B. Bender, Stonehenge: Making Space, Oxford: Berg. Bianchi, R. (2002) 'the contested Landscapes of World Heritage on a Tourist Island: the case of Garajonay National Park, La Gomera, International Journal of Heritage Studies 8, no. 2. (1999).

${ }^{2}$ A. Emge, Old Order in New Space: Change in the Troglodytes' Life in Cappadocia, in: Change in Traditional Habitat; Traditional Dwellings and Settlements Working Paper Series, 37, (Berkeley: University of California, 1992).
} 
more harmoniously than conventional buildings. And also, their design offers extra protection against high winds, hailstorms, and natural disasters such as tornados, hurricanes and earthquakes. A big advantage of building repositories underground is that the environment is very stable ${ }^{1}$.

\section{Disadvantages of Underground Buildings}

There are few disadvantages about underground buildings which can be dispelled by appropriate design. Humidity which is advantages in arid climate in some cases can be disadvantages, hence, the level of care required to avoid moisture problems, during both the construction and the life of the building. Nevertheless, with certain precautions, like special waterproofing, the humidity can be controlled. Also, Principal downsides are the initial cost of construction, which may be up to $20 \%$ higher than ordinary construction.

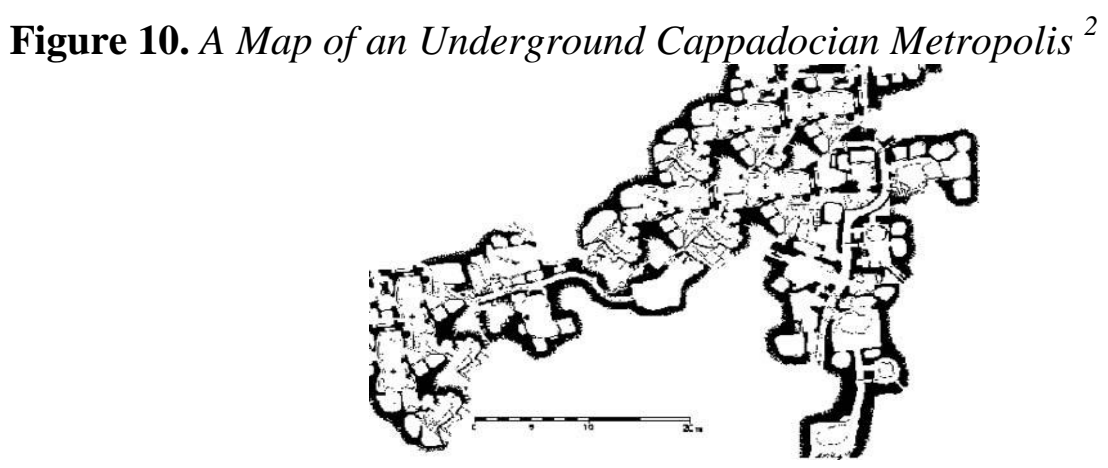

Since the 60's the Cappadocian Troglodytes from the village Göreme and other settlements started to leave their centuries old caves sometimes against their own will - and began to move into newly built houses subsidized by the government. This movement is caused by different facts. Furthermore the ideas and the taste of the inhabitants have been altered by a slight economic up swing, the influence of mass media and the ever growing tourist business, which of course again alters the infra structure and creates a desire for modern housing. Another major influence, which can be observed were the families who went as workers to western Europe or in big towns in Turkey. These people came back with new ideas of habitation and living facilities that they have integrated through the process of migration ${ }^{3}$.

\footnotetext{
${ }^{1}$ René Teygeler, Preservation of Archives in Tropical Climates. An annotated bibliography, Paris: Comma,2001.

${ }^{2}$ C.M. Hall and S. McArther, The Human dimension of heritage management: different values, different interests, different issues, in Hall, C M \& McArthur, S (eds) Heritage Management in Australia and New Zealand: 2-21 (Oxford University Press, 1996).

${ }^{3}$ A. Emge, Old Order in New Space: Change in the Troglodytes' Life in Cappadocia, in: Change in Traditional Habitat; Traditional Dwellings and Settlements Working Paper Series, 37, (Berkeley: University of California, 1992).
} 
Sometimes up to $40 \mathrm{~cm}$ higher lies the actual living room, that is furnished with carpets, pillows and blankets. In rural areas of Turkey people traditionally only use one room for daily life but it is furnished to accommodate many functions in a simple and practical way. This is a multi-functional living room, lending itself to eating, sitting and sleeping. All utensils are placed at the sides of the room, so that the centre is principally left empty and can fulfil many different functions. During the daytime between the meals this central area is left open. Luxurious pillows and blankets as sitting facilities are lined up along the walls. The walls feature small niches and wallshelfs in which bedding and personal things are kept. Even small washing facilities are hidden in walls screened by a small wooden door or curtain, barely devised from the sitting room ${ }^{1}$.

It is quite remarkable that the so far described horizontal division of space from the village centre to the quarters and households is now changed into a vertical one, in which the higher lying areas are considered to be purer and higher in rank than the lower ones. As already stated the lower lying entrance area is reserved for shoes and dirt. The ground floor of the higher arranged living room and here especially the area close to the door is the space reserved for women and children. Therefore there is always the possibility of being seated higher as well as lower then someone else.

Figure 11. A View from a Living Space in Underground City

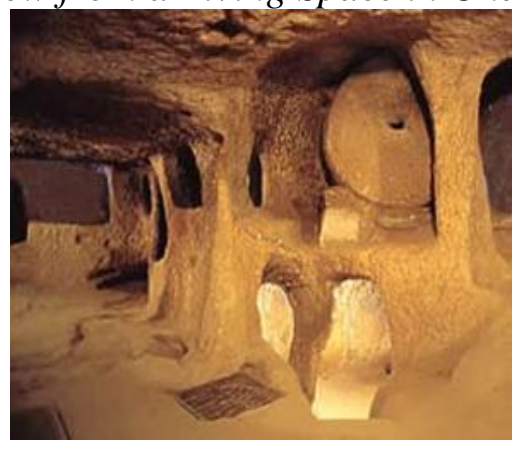

This dichotomy in room division and symbolism is extended further upward: At standing- and reaching height there is often a shelf attached to the wall, going all around the room where decorative objects and utensils of daily use are placed and exhibited. This is the upper level boundary line of space used by the inhabitants ${ }^{2}$.

The fields of architecture and urban design would do well to center their sustainable sights on this unique site few structures outside of this area in

\footnotetext{
${ }^{1}$ A. Leask, and A. Fyall, "World Heritage sites: Current Issues and future Implications", in Robinson, M., Evans, N., Long, P., Sharpley, R.and Swarbrooke, J. eds. Tourism and Heritage Relationships: Global, National and Local Perspectiives, (Sunderland: Centre for Travel and Tourism and Business Education, 2000).

${ }^{2}$ A. Leask, and A. Fyall, "World Heritage sites: Current Issues and future Implications", in Robinson, M., Evans, N., Long, P., Sharpley, R.and Swarbrooke, J. eds. Tourism and Heritage Relationships: Global, National and Local Perspectiives, (Sunderland: Centre for Travel and Tourism and Business Education, 2000).
} 
Cappadocia have survived for so long. Some of these buildings go up to five full stories underground and date back to Roman times or beyond, though many caves were carved out by human hands long before their empire arrived.

\section{Results and Conclusions}

The fantastic rock formations used as shells for these dwellings date back millions of years, and much of the more recent architecture has survived for hundreds or even thousands of years despite being laid siege to many times over and housing everything from armies to explosive weapons factories. In part due to their secret locations and the naturally temperature-controlled nature of the cave interiors, many religious artifacts and artworks have survived for over a thousand years. All the while, surface structures have been erected and destroyed while modern architecture mixes in strange hybrids with historic temples and above-ground houses. Since almost two thousand years the cave dwellings of Cappadocia play a major role in the regional architecture. During that period many different cultures inhabited this area and used special cave dwellings due to their internalized specific needs. The climate inside is optimal for living and storing: cool in summer and warm in winter. Under the aspect of the current conditions and sustainable usage criteria the general aspect to load the necessary function to a cave house should depend upon;

- The geographical position and location of the cave

- The quality of the physical and social abilities of the cave interior for the chosen function to be loaded.

- Determining the environmental aspects of the cave before making the interior space designing.

- Creating sustainable interior abilities in order to use the caves depending the nature of their presence.

- Creating functions like museums, artistic and cultural functions as for public usage to reach the most essential spatial organization.

New architectural elements and the needs of modern life should be combined with the local building styles. In Cappadocia, where even the western tourists enjoy the cave dwelling culture by preferring pensions build inside the tuffa, there will be a good chance of revalorizing this extraordinary and functional housing type by building new tuffa caves combined with modern technical elements which symbolize prestigious values. Strategies for energy conservation are specific problems that arise from the characteristics of the building. Each building type and region should be considered differently. To be able to consume less energy in buildings there are two basic options: invest heavily in the purchase, installation, operation and maintenance of necessary technical systems; or reduce energy load by applying bioclimatic principles to building design. 


\section{References}

Adams, Celeste, "Cave Dwellers", The Magic of Living in the Earth, http://www. spiritofmaat.com/archive/apr2/trogs.htm

Ashrafian, T., F., N., Moazzen and M. Haghlesan. "Human Comfort in Underground Buildings". Presentation at 5th Sastech 5th Symposium on Advances in Science and Technology, Paper Reference Number: 0602-958, Khavaran Highereducation Institute, 2011.

Bender, B. Stonehenge: Making Space. Oxford: Berg, 1999.

Bianchi, R. "The contested Landscapes of World Heritage on a Tourist Island: the case of Garajonay National Park, La Gomera", International Journal of Heritage Studies 8, no. 2, (2002).

Derinkuyu, or the Allure of the Underground City", last modified August 19, 2007, http:// bldgblog.blogspot.com/2007/08/derinkuyu-or-allure-of-underground-city.html

Emge, A. Old Order in New Space: Change in the Troglodytes' Life in Cappadocia, in: Change in Traditional Habitat; Traditional Dwellings and Settlements Working Paper Series 37, Berkeley: University of California, 1992. http://andusemge.de/Texte/IASTEBerkeley1992.pdf

Erdem, A. "Subterranean space use in Cappadocia: The Uchisar example", Tunnelling and Underground Space Technology 23, Iss. 5, 2008.

Evans, G. "Living in a World heritage City: stakeholders in the dialectic of the universal and particular", International Journal of Heritage Studies 8, no. 2, (2002): 117-135. Explore Worldwide 'Turkey' video promotion, Explore Worldwide Ltd, 1989.

Garrod, B. and A. Fyall, "Managing Heritage Tourism', Annals of Tourism Research, 27, (2000).

Hall, C.M. and S. McArther, "The Human dimension of heritage management: different values, different interests, different issues", in Hall, C M \& S McArthur, (eds) Heritage Management in Australia and New Zealand: 2-21. Oxford University Press, 1996.

Harrison, D. "Introduction: contested arratives in the Domain of World Heritage" (2005 ), 1-10, in Harrison, D. and Hitchcock, M. (eds) (2005) The Politics of World Heritage: Negotiating Tourism and Conservation, Clevedon: Channel View Publications. Kayakapi Projesi, 2005. Available at: http://www.kaya kapi.com

Kinzer, S. 'Live Better, Live Longer, in My Home, Sweet cave!', The New York Times International, May 2, 1997.

Kücükerman, Ö. Turkish House in Search of Spatial Identity, Istanbul: Turkish Touring and Automobile Association, 1985.

Leask, A. and Fyall, A. 'World Heritage sites: Current Issues and future Implications', in Robinson, M., Evans, N., Long, P., Sharpley, R.and Swarbrooke, J. (eds.) Tourism and Heritage Relationships: Global, National and Local Perspectives, Sunderland: Centre for Travel and Tourism and Business Education, 2000.

Öztürk, F. G. "The Unusual Separatıon Of Cappadocian Refectorıes And Kitchens: An Enigma Of Architectural History", DOI: 10.4305/ METU.JFA.2012.1.9, METU JFA 2012/1, (29:1), 2012, 153-169. http://jfa.arch.metu.edu.tr/archive/02585316/2012/cilt29/sayi_1/153-169.pdf

Rodley, L. Cave Monasteries of Byzantine Cappadocia. New York: Cambridge University Press, 1985, xviii +266 pp 
Sözer, H., and S. Bekele. Evaluatıon of Innovatıve Sustainable Design Technics that Comes from Traditional Architecture, 2011. Proceedings of the ASME 2011 5th International Conference on Energy Sustainability ES2011, Washington, DC, USA ES2011-54

Stryker, Catherine, Blown Away in Cappadocia, http://www.gonomad.com/destinatio ns/0407/cappadocia.html

Timothy, D.J. and S.W. Boyd, Heritage Tourism, London: Prentice Hall, 2003.

Tosun, C. "Roots of unsustainable tourism at the local level: the case of Ürgüp in Turkey", Tourism Management 19, 1998, 595-610.

Tucker, H. "Tourism and the Loss of Memory in Zelve, Cappadocia", Journal of the Oral History Society 28, no.2 (2000): 79-88.

Tucker, H. "Kapadokya, Zelve'de Miras, Bellek ve Deneyim”, in E. Ozyurek ed. Turkiye'nin Toplumsal Hafizasi, Istanbul: Iletisim, 2001, 249-266.

"Underground Cities: 3500 Years of Cappadocian Cave Homes", http://dornob.com/ underground-cities-3500-years-of-cappadocian-cave-homes/\#ixzz3OKeCa9E5

Urry, J. "The Tourist Gaze and the Environment", Theory, Culture and Society 9, (1992): 1-26.

Winter, T. "Landscape, memory and Heritage: New Year Celebrations at Angkor, Cambodia", in Harrison, D. and Hitchcock, M. ed. The Politics of World Heritage: Negotiating Tourism and Conservation, Clevedon: Channel View Publications, (2005): 50-65. 